\title{
INVESTIGATION OF RELATIONSHIP BETWEEN PSYCHOLOGICAL WELL-BEING, SELF ESTEEM, PERCEIVED GENERAL SELF-EFFICACY, LEVEL OF HOPE AND COGNITIVE EMOTION REGULATION STRATEGIES
}

\author{
O. Nejat Akfirat ${ }^{\mathrm{i}}$ \\ Kocaeli University, \\ Turkey
}

\begin{abstract}
:
In this study, the relationship between pre-service teachers' psychological well-being levels and self-esteem, perceived general self-efficacy, cognitive emotion regulation strategies and hope variables were investigated together with how these variables predicted pre-service teachers' psychological well-being. The research was conducted via relational screening model. The research group consists of a total of 403 participants including 206 females and 197 males, who received pedagogical formation education at a university located in Turkey's Marmara Region, and participants were selected using a simple random sampling method. In the research, Psychological Well-Being Scale (short form), Rosenberg Self-Esteem Scale, General Self-Efficacy Scale, Cognitive Emotion Regulation Scale, the Beck Hopelessness Scale, and Personal Information Form were used as data collection tools. The data obtained were analyzed by multiple linear regression analysis. According to the findings, self-esteem, general self-efficacy, level of hope, positive reappraisal from cognitive emotion regulation strategies, accusing and accepting others significantly predicted psychological well-being.
\end{abstract}

Keywords: psychological well-being, general self-efficacy, self-esteem, hopelessness, cognitive emotion regulation strategies

\section{Introduction}

Research trends related to people's well-being gained momentum with the development of a positive psychological perspective. Well-being is a complex structure in which experience and functioning are concerned. Current research on well-being is derived from two general perspectives: the first one is a hedonic approach focusing on happiness and defining happiness in terms of enjoyment and avoiding pain (hedonism) and the

i Correspondence: email nejatakfirat@gmail.com 
INVESTIGATION OF RELATIONSHIP BETWEEN PSYCHOLOGICAL WELL-BEING, SELF ESTEEM, PERCEIVED GENERAL SELF-EFFICACY, LEVEL OF HOPE AND COGNITIVE EMOTION REGULATION STRATEGIES

second one is and the eudemonic approach that focuses on meaning and self-realization and defining well-being in terms of a person's degree of functioning (Ryan \& Deci, 2001). Subjective well-being is associated with goodness in terms of overall life satisfaction and happiness, while psychological well-being uses more holistic human development approach (Keyes et al., 2002: 1008). From this point of view, while subjective well-being focuses on the individual's subjective evaluations, psychological well-being is more about realizing its potential and being in full function (Morsünbül, 2011: 64).

Ryff, the advocate of psychological well-being, defines well-being not only as a way to enjoy it but as "striving for perfection that represents the realization of one's true potential" (1995, p. 100). Ryff presents a multidimensional approach to psychological wellbeing, addressing six different aspects of human beings, stating that psychological wellbeing developed concerning the theories of Erikson, Jung, Rogers, Maslow, Jahoda, Allport, Bühler, Neugarten and Frankl which are available in the psychology literature (Ryff, 1989). According to this model, psychological well-being dimensions are as follows: "Self-Acceptance", which is defined as having a positive attitude towards him/herself and his/her past; "Positive Relations with Others" defined as warm, reliable and positive relationships with others; "Autonomy" defined as the sense of making own decisions, freedom, the focus of internal control; "Environmental Domination" defined as the capacity of creating a suitable environment according to the personal and spiritual conditions of the person; "Individual Development" defined as having the feeling that the person is constantly developing and growing as an individual and "Aim of Life" defined as having a sense of finding meaningful life (Ryff, 1989; Ryff \& Keyes, 1995; Keyes et al., 2002).

The psychological well-being put forward by Ryff (1995), can also be considered as an indicator of the positive mental health discussed in the psychology literature (Button et al., 1997; Liu, Shono \& Kitamura, 2009). Sustainable well-being does not always require individuals to feel good; The experience of painful emotions (such as frustration, failure, grief) is a normal part of life, and being able to manage these negative or painful emotions is essential for long-term well-being. However, psychological well-being is endangered when negative emotions are excessive or too long and the individual's ability to work in daily life is hindered (Huppert, 2009). Effective coping skills are needed to maintain well-being.

In this study, the relationship between cognitive emotion regulation strategies, general self-efficacy perception, self-esteem, and hope level which are determined to be effective in the literature in coping with compelling experiences of the individual, and psychological well-being is examined. Emotion regulation is defined as involving all conscious and unconscious strategies that individuals use to reduce, maintain, or increase positive or negative emotions (Gross, 2001). Cognitive emotion regulation refers to controlling and evaluating emotions and overcoming troublesome situations and emotions through cognitive processes (Onat \& Otrar, 2010). Cognitive emotion regulation strategies, which are also used as coping theory, are classified as adaptive and maladaptive strategies (Garnefski et al., 2001; Garnefski \& Kraaij, 2006; Garnefski \& 
INVESTIGATION OF RELATIONSHIP BETWEEN PSYCHOLOGICAL WELL-BEING, SELF ESTEEM, PERCEIVED GENERAL SELF-EFFICACY, LEVEL OF HOPE AND COGNITIVE EMOTION REGULATION STRATEGIES

Kraaij, 2007; Kraaij, et al., 2008; Thompson, 1991). Adaptive strategies are associated with optimism, self-esteem, psychological well-being, while maladaptive strategies are associated with an emotional problem, depression, psychopathology (Aldoa \& NolenHoeksama, 2010; Anderson et al., 1994; Andres et al., 2016; Garnefski et al., 2001; Garnefski et al., 2002; Garnefski \& Kraaij, 2006; Garnefski \& Kraaij, 2007; Garnefski \& Kraaij, 2016; Kraaij et al., 2007; Kraaij et al., 2008; McGee, et al., 2001; Schroevers, et al., 2007; Thompson, 1991). Difficulties in emotional control can affect life negatively. Cognition or cognitive processes can help individuals manage their emotions, which they may experience after difficult life events, and thus overcome these emotions (Garnefski et al., 2001). Emotion regulation is considered as an important factor in determining the functioning of well-being state (Cicchetti, et al., 1995; Thompson, 1991).

Bandura (1986, 1997), one of the representatives of social learning theory, defined self-efficacy expectations as the determinant of individuals' behavior. Self-efficacy, which is defined as the strongest predictor of human behavior, is the beliefs of individuals about their ability to create certain effects in their desired fields (Bandura, 1997). According to Bandura $(1977,1982)$, individuals' perception of competence assessments in a field can be generalized to competency assessments in similar fields. Scherbaum, Cohen-Charash, and Kem (2006) conceptualized this situation as "general self-efficacy". General selfefficacy is defined as the self-efficacy belief in coping with the compelling experiences of the individual (Scholz \& Schwarzer, 2005).

Another concept associated with psychological well-being is self-esteem. Rosenberg (1965) has defined self-esteem as "feeling valuable in general". According to another definition, self-esteem is defined as an important resource for the individual to form a positive self-assessment (Hobfoll, 1989). Self-esteem reflects a person's overall subjective emotional assessment of their own value (Lopez \& Snyder, 2004). Coping resources for individuals with low self-esteem are limited that could be used against compelling experiences to support an individual's mental health. (Taylor \& Stanton, 2007). There are many studies in the literature on self-esteem. While high self-esteem is associated with general well-being, low self-esteem is assumed to have damaging effects (Crocker \& Park, 2004; Dubois \& Flay, 2004; Dogan, et al., 2013; Fergusson \& Lynskey, 1996; Karaırmak, Siviş Çetinkaya, 2011; Wang, \& Castañeda-Sound, 2008). It is accepted that individuals with high self-esteem adapt better and have a positive perspective on them.

Hopelessness is defined as the expectation that positive events will not occur in the future and/or the belief that negative events will occur and the individual will not be able to do anything to change this situation (Abela \& Seligman, 2000; Abramson et al., 1989; Beck et al., 1974; Weishaar \& Beck, 1992). Individuals often experience the feeling of hopelessness when they regard themselves as helpless and worthless when they think that the consequences of the events they experience and will experience in the future cannot be changed and that they are not able to control them (Abramson et al., 1989). High level of hopelessness was found to be associated with, depression (Mac Giollabhui, et al., 2018; Marchetti et al., 2016) and suicide (Franklin et al., 2017). On the other hand, 
low level of hopelessness contributes to individuals staying strong against compelling experiences (Kylma, 2005). According to the researchers, hope is a healing power (Holdcraft \& Williamson, 1991) a source of resistance to negative situations (Peterson et al., 2007). Hope acts as a protection for the individual.

In light of all this information, it is thought that there may be a relationship between psychological well-being and self-esteem, general self-efficacy perception, hopelessness, and cognitive emotion regulation strategies. It is thought that the findings regarding the nature of the psychological well-being will contribute to the literature. With the data obtained, it is expected to identify the variables that affect the mental health of individuals and to shed light on the measures to be taken.

In this research, the relationship between these six structures will be examined. Within the framework of this general purpose, answers to the following questions will be sought.

1) Is there a significant relationship between the participants' self-esteem, general self-efficacy, hopelessness, adaptive cognitive emotion regulation strategies, maladaptive cognitive emotion regulation strategies, and psychological wellbeing levels?

2) Do self-esteem, general self-efficacy, hopelessness, adaptive cognitive emotion regulation strategies, maladaptive cognitive emotion regulation strategies predict the level of psychological well-being?

\section{Material and Methods}

\subsection{Research Model}

The research is carried out via relational screening model. In this model, the degree of covariation between two and more variables is attempted to be determined (Karasar, 2012). The research aims to reveal the relationship between at least two variables that examine whether self-esteem, general self-efficacy, hopelessness, and cognitive emotion regulation levels are predictive for the level of psychological well-being.

\subsection{Participants}

The data of the research were collected from students who continue their pedagogical training at a university in Marmara region in Turkey. Attention was paid to the balanced distribution of the sexes of the participants to prevent investigated variables from being affected by the gender variable. Accordingly, 206 (51\%) of the total 403 participants were female and $197(49 \%)$ were male and $35.5 \%(n=140)$ of the participants had a university diploma, whereas $64.5 \%(n=254)$ were senior students in a university. The average age of the participants was 27.7 .

\subsection{Data Collection Tools}

Psychological Well Being Scale Short Form (PWB-42) 
It was developed by Ryff (1989) and the study of adapting the 84-item version of the scale to Turkish was carried out by Akın (2008). In this study, a short-form developed by Akın et al. (2012) was used. The scale is a 7-grade Likert type scale. 42 items in the scale measuring the psychological well-being of the individual. It consists of six subscales: "Autonomy", "Environmental Domination", "Individual Development", "Positive Relations with Others", "Life Purposes" and "Self-Acceptance". There are 7 items and reverse codes in each subscale. The highest score that can be obtained from the scale is 294 and the lowest score is 42 . In the results of confirmatory and exploratory factor analysis, the scale was accepted as six-dimensional, adhering to the original. Confirmatory factor analysis findings of the short form revealed that six sub-dimensional models were significant (RMSEA=.048, NFI=.92, NNFI = 94, CFI=.95, IFI= .95, RFI=.92, $\mathrm{GFI}=.90$, and $\mathrm{SRMR}=.048$ ). In the short form, the Cronbach Alpha coefficients for each subscale ranged from .92 to .97 . The reliability coefficients for this research group and the subscales are between .79 and.91.

\section{A. Beck Hopelessness Scale}

Beck Hopelessness Scale (BHS) was developed by Beck, Weissman, Lester, and Trexler in 1974 to examine psychopathological conditions that reflect hopelessness. There are two options for questions on the 20-item scale, right and wrong, and the total score to be obtained varies between 0-20 (Beck, et al., 1974). Scale internal consistency reliability coefficient was obtained as 0.93 and Turkish adaptation of the scale was carried out by Seber (1991). There are three sub-dimensions in the scale: "Emotions and expectations about the future (5 items)", "Motivation loss (8 items)" and "Hope (7 items)" (Durak \& Palabiyık, 1994). The internal consistency coefficient in the reliability study of the scale was found 0.86 in a study of patients with depression, whereas it was found to be 0.85 in a study of normal and psychiatric patients (Durak \& Palabiyık, 1994). Item-total score correlations of the scale were calculated between 0.07-0.72 in Seber (1991) and between 0.31-0.67 in Durak \& Palabiyık (1994). Also, split half-reliability was 0.85 and test-retest reliability was 0.74 . Within the scope of the study, the KR-20 internal consistency coefficient was determined as 0.80 for the entire 20-item scale. KR-20 reliability coefficient; It was found to be 0.67 for the sub-dimension 'Emotions and expectations about the future', 0.57 for the 'loss of motivation' sub-dimension, and 0.51 for the 'hope' sub-dimension. The Cronbach alpha internal consistency coefficient of the scale calculated for this study is 0.84 .

\section{B. General Self-Efficacy Scale}

The scale, which was developed by Schwarzer and Jarusalem as 20 items in 1979, was revised in 1981 and reduced to 10 items (Aypay, 2010). Adaptation to Turkish culture was carried out by Aypay in 2010. The scale evaluates the belief in the ability to cope with new and difficult tasks in different settings. The scale, which consists entirely of positive items, was prepared in a 4-point Likert type. The internal consistency coefficient (C-A) of the scale, which has a single-factor structure, was determined as 0.86 . The test-retest 
INVESTIGATION OF RELATIONSHIP BETWEEN PSYCHOLOGICAL WELL-BEING, SELF ESTEEM, PERCEIVED GENERAL SELF-EFFICACY, LEVEL OF HOPE AND COGNITIVE EMOTION REGULATION STRATEGIES

reliability of the scale was determined to be 0.80 . The scale translated into many languages has been used in many studies (Aypay, 2010). Within the scope of the study, Cronbach Alpha's internal consistency coefficient of the general self-efficacy scale was determined as $\mathrm{C}-\mathrm{A}=0.77$. The Cronbach alpha internal consistency coefficient of the scale calculated for this study is 0.87 .

\section{Rosenberg Self-Esteem Scale (RSES)}

RSES (Rosenberg, 1965) was used to determine the self-esteem levels of the participants. The validity and reliability studies of the scale in our country were carried out by Çuhadaroğlu (1986). The validity of the scale was examined through psychiatric interviews and reported as .71. The test-retest reliability of the scale reported at onemonth interval is .75 (Çuhadaroğlu, 1986). The scale is a four-point Likert-type scale consisting of ten items and the participants indicate how appropriate each scale item is for them by checking one of the options ranging from Strongly Disagree (1) to Strongly Agree (4). The scores that can be obtained from the scale vary between 10 and 40 . The increase in the scores obtained from the scale indicates that the self-esteem levels of the individuals have increased. The Cronbach alpha internal consistency coefficient of the scale calculated for this study is .85 .

\section{Cognitive Emotion Regulation Scale (CERS)}

Cognitive Emotion Regulation Scale is a 5-point Likert type scale developed by Garnefski et al. (2001). The scale consists of 36 items, and it consists of a total of nine sub-dimensions "self-blame", "acceptance", "rumination", "positive refocus", "refocus on the plan", "positive reappraisal", "putting into perspective", "catastrophizing", and "blaming others". Acceptance, refocusing on the plan, positive refocusing, positive reappraisal, and putting into perspective are considered as adaptive while self-blame, blame others, rumination, and catastrophizing are considered as maladaptive coping strategies. The scale can measure cognitive emotion regulation strategies that people use both against certain events or situations and can be applied to adults and adolescents over 12 years of age in normal and clinical samples. In previous studies, all subscales showed good internal consistency ranging from .68 to .86 (Garnefsi et al. 2002). The Cronbach Alpha value of the scale, which was adapted to Turkish by Onat and Otrar (2010), was determined as $\alpha=.784$ and test-retest reliability coefficient was determined as " $r=.1,00$ ". A statistically significant relationship was obtained between the Cognitive Emotion Regulation Scale and the Negative Emotion Status Scale ( $r=$.-572) (Onat \& Otrar, 2010).

\subsection{Data Analysis}

Descriptive statistics were used in the study to examine students' hopelessness, selfesteem, general self-efficacy, cognitive emotion regulation, and psychological well-being levels. Psychological well-being $(S C=-0.412, K C=-0.130)$, self-esteem $(S C=-0.535, K C=-$ $0.289)$, general self-efficacy $(S C=-0.489, K C=0.305)$, acceptance $(S C=0.029, K C=-0.051)$, refocus on the plan $(S C=-0.891, K C=1.169)$, positive refocus $(S C=-0.045, K C=-0.265)$, 
positive reappraisal $(\mathrm{SC}=-0.446, \mathrm{KC}=-0.068)$, putting into perspective $(\mathrm{SC}=-0.116, \mathrm{KC}=$ $0.118)$, self-blame $(S C=0.105, K C=0.200)$, blaming others $(S C=0.358, K C=0.473)$, rumination $(\mathrm{SC}=-0.384, \mathrm{KC}=0.349)$ and catastrophizing $(\mathrm{SC}=-0.390, \mathrm{KC}=-0.046)$ were found to be normally distributed while the hopelessness $(\mathrm{SC}=1.382, \mathrm{KC}=1.274)$ variable was found to show a positively skewed distribution. The skewness coefficients in the range of -1 and +1 this shows that the scores obtained for the six variables do not deviate much from the normal distribution and can be considered normal (Büyüköztürk, et al., 2012). The square root transformation was made for hopelessness scores and the data were normalized (Tabachnick \& Fidell, 2007). As a result of the transformation, the skewness coefficient for the hopelessness variable was 0.759 and the kurtosis coefficient was -0.092 .

The Pearson Moments Product Correlation Coefficient was used to describe the relationship since the data on thirteen variables were obtained continuously and at least in equal intervals. Self-esteem, general self-efficacy, hopelessness, self-blame, acceptance, rumination, positive refocusing, refocus on the plan, positive reappraisal, putting it in perspective, catastrophizing, and blaming others; stepwise regression analysis was used to determine whether psychological well-being is a significant predictor. In progressive regression analysis, each variable is added sequentially to the model and the model is evaluated. If the added variable contributes to the model, this variable remains in the model. However, all other variables in the model are retested to assess whether they contribute to the model or not. The variable that does not contribute significantly is removed from the model. In this way, the model is explained with the help of the least number of variables (Kalayc1, 2009).

VIF and Durbin Watson coefficients were checked for multiple linear connection problems and autocorrelation. VIF values were found in the range of $1.161-1.785$, respectively. The Durbin Watson coefficient for the regression equation was obtained as 2.006. SPSS 23 package program was used for statistical analysis of the data.

\section{Findings}

In this section, the findings obtained in the research are presented according to the research questions. Descriptive statistics for the three variables discussed in the study are given in Table 1.

As seen in Table 1, the arithmetic average of the participants' psychological wellbeing scores was determined as $208.95 \pm 26.62$. The high scores obtained from the scale indicate the high level of psychological well-being. The arithmetic average of the participants' self-esteem scores was determined as $31.87 \pm 5.22$. High scores from the scale indicate high self-esteem. The arithmetic average of the participants' general self-efficacy scores was determined as $31.36 \pm 5.44$. Although the cutoff scores were not determined during the adaptation phase of the scale, the high scores obtained from the scale indicate high levels of self-efficacy. The arithmetic mean of hopelessness scores was determined as $4.53 \pm 4.13$. Hopelessness scores, $0-3$ points indicate that there is no hopelessness, $4-8$ 
INVESTIGATION OF RELATIONSHIP BETWEEN PSYCHOLOGICAL WELL-BEING, SELF ESTEEM, PERCEIVED GENERAL SELF-EFFICACY, LEVEL OF HOPE AND COGNITIVE EMOTION REGULATION STRATEGIES

points indicate mild hopelessness, 9-14 points indicate medium hopelessness, and 15-20 points indicate severe hopelessness (Beck and Steer, 1988; as cited in Aslan, 2013). It has been observed that out of a total of 403 participants, from whom the research data were collected, 218 (55\%) had no hopelessness, 119 (30\%) had mild hopelessness, 49 (12\%) had moderate hopelessness, and $14(3 \%)$ had severe hopelessness.

Table 1: Descriptive Statistics of Variables

\begin{tabular}{|c|c|c|c|c|c|c|c|c|c|}
\hline Variables & 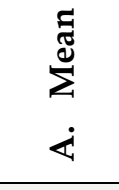 & 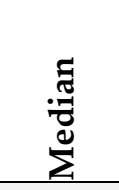 & $\begin{array}{l}\bar{\infty} \\
0 \\
3 \\
0\end{array}$ & 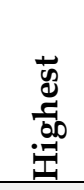 & 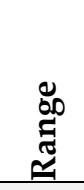 & 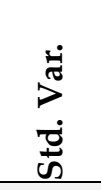 & 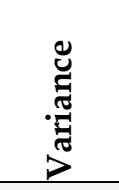 & 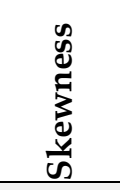 & $\frac{n}{\infty}$ \\
\hline Psychological Well-Being & 208.95 & 211.00 & 101 & 267 & 166 & 26.62 & 708.45 & -0.412 & 0.130 \\
\hline Self Esteem & 31.87 & 33.00 & 17 & 40 & 23 & 5.22 & 27.28 & -0.535 & -0.289 \\
\hline Hopelessness & 4.53 & 3.00 & 0 & 19 & 19 & 4.13 & 17.03 & 1.382 & 1.274 \\
\hline $\begin{array}{l}\text { Hopelessness (Square } \\
\text { Root Transformation) }\end{array}$ & 2.21 & 2.00 & 1 & 4.47 & 3.47 & 0.80 & 0.65 & 0.759 & -0.092 \\
\hline General Self Efficacy & 31.36 & 32.00 & 10 & 40 & 30 & 5.44 & 29.63 & -0.489 & 0.305 \\
\hline Acceptance & 11.82 & 12.00 & 5 & 19 & 14 & 2.70 & 7.27 & 0.029 & -0.051 \\
\hline Refocus on the Plan & 15.41 & 16.00 & 4 & 20 & 16 & 3.24 & 10.53 & -0.891 & 0.726 \\
\hline Positive Refocus & 12.48 & 12.00 & 6 & 19 & 13 & 2.59 & 6.71 & -0.045 & -0.265 \\
\hline Positive Reappraisal & 14.67 & 15.00 & 4 & 20 & 16 & 3.33 & 11.06 & -0.446 & -0.068 \\
\hline Putting in the Perspective & 12.97 & 13.00 & 4 & 20 & 16 & 2.90 & 8.41 & -0.116 & 0.118 \\
\hline Self-Blame & 11.63 & 12.00 & 5 & 18 & 13 & 2.14 & 4.59 & 0.105 & 0.200 \\
\hline Blaming Others & 10.80 & 11.00 & 4 & 20 & 16 & 2.72 & 7.40 & 0.358 & 0.473 \\
\hline Rumination & 14.48 & 15.00 & 4 & 20 & 16 & 2.88 & 8.28 & -0.384 & 0.349 \\
\hline Catastrophizing & 10.02 & 10.00 & 4 & 20 & 16 & 3.51 & 12.30 & 0.390 & -0.046 \\
\hline
\end{tabular}

The arithmetic mean of the acceptance scores of the participants' cognitive emotion regulation sub-scales of the adaptive cognitive emotion regulation scale is $11.82 \pm 2.70$, the arithmetic mean of the points to refocus on the plan is $15.41 \pm 3.24$, the arithmetic mean of the positive refocus points is $12.48 \pm 2.59$, the arithmetic mean of the positive reappraisal points is $14.67 \pm 3.33$, arithmetic mean of putting in the perspective scores is $12.97 \pm 2.90$; maladaptive cognitive emotion regulation sub-scales; the arithmetic mean of self-blame scores, was $11.634 \pm 2.14$, the arithmetic mean of blaming others was $10.80 \pm$ 2.72 , the arithmetic mean of the rumination was $14.48 \pm 2.88$ and the mean of catastrophizing was $10.02 \pm 3.51$. The score for each subscale can vary between 4 and 20, evaluation is performed with the scores obtained from the subscales. The high score obtained from a subscale indicates that the strategy determined by that subscale is used more. 
O. Nejat Akfirat

INVESTIGATION OF RELATIONSHIP BETWEEN PSYCHOLOGICAL WELL-BEING, SELF ESTEEM, PERCEIVED GENERAL SELF-EFFICACY, LEVEL OF HOPE AND COGNITIVE EMOTION REGULATION STRATEGIES

Table 2: Correlation coefficients between variables

\begin{tabular}{|c|c|c|c|c|c|c|c|c|c|c|c|c|c|}
\hline Variables & 1 & 2 & 3 & 4 & 5 & 6 & 7 & 8 & 9 & 10 & 11 & 12 & 13 \\
\hline 1. Psychological Well-Being & 1 & & & & & & & & & & & & \\
\hline 2. Self Esteem & $.662^{* *}$ & 1 & & & & & & & & & & & \\
\hline 3. Hopelessness & $-.602^{* *}$ & $-.612^{* *}$ & 1 & & & & & & & & & & \\
\hline 4. Hopelessness (Square Root Transformation) & $.486^{* *}$ & $.467^{* *}$ & $-.374^{* *}$ & 1 & & & & & & & & & \\
\hline 5. General Self Efficacy & $-.287^{* *}$ & $-.230^{* *}$ & $.260^{* *}$ & $-.215^{* *}$ & 1 & & & & & & & & \\
\hline 6. Acceptance & $.329^{* *}$ & $.324^{* *}$ & $-.280^{* *}$ & $.229^{* *}$ & $-.099^{*}$ & 1 & & & & & & & \\
\hline 7. Refocus on the Plan & $.236^{* *}$ & $.275^{* *}$ & $-.191^{* *}$ & $.133^{* *}$ & .025 & $.420^{* *}$ & 1 & & & & & & \\
\hline 8. Positive Refocus & $.396^{* *}$ & $.358^{* *}$ & $-.339^{* *}$ & $.279^{* *}$ & -.077 & $.785^{* *}$ & $.474^{* *}$ & 1 & & & & & \\
\hline 9. Positive Reappraisal & $.122^{*}$ & $.109^{*}$ & $-.124^{*}$ & .087 & $.145^{* *}$ & $.395^{* *}$ & $.423^{* *}$ & $.517^{* *}$ & 1 & & & & \\
\hline 10. Putting in the Perspective & $-.255^{* *}$ & $-.265^{* *}$ & $.187^{* *}$ & $-.184^{* *}$ & $.372^{* *}$ & -.013 & -.053 & -.058 & .096 & 1 & & & \\
\hline 11. Self-Blame & $-.175^{* *}$ & -.092 & $.163^{* *}$ & -.048 & $.153^{* *}$ & $-.103^{*}$ & -.014 & -.071 & .060 & $.122^{*}$ & 1 & & \\
\hline 12. Blaming Others & -.046 & -.020 & .073 & -.081 & $.266^{* *}$ & $.421^{* *}$ & .059 & $.323^{* *}$ & $.273^{* *}$ & $.295^{* *}$ & .091 & 1 & \\
\hline 13. Rumination & $-.285^{* *}$ & $-.276^{* *}$ & $.295^{* *}$ & $-.197^{* *}$ & $.257^{* *}$ & $-.303^{* *}$ & $-.119^{*}$ & $-.273^{* *}$ & -.066 & $.254^{* *}$ & $.442^{* *}$ & .068 & 1 \\
\hline
\end{tabular}
${ }^{*} \mathrm{p}<.05^{* *} \mathrm{p}<.01$

As seen in Table 2, the correlation between psychological well-being, self-esteem, general self-efficacy, hopelessness, and scores of cognitive emotion regulation strategies were investigated in the research. It was found that there was a significant positive correlation between the scores of general self-efficacy, self-esteem, refocusing on the plan, positive refocus, positive reappraisal, and putting in the perspective and there was a significant negative correlation between hopelessness, acceptance, self-blame, blaming others, and catastrophizing scores. Correlations obtained show that; as hopelessness increases, scores of psychological well-being, self-esteem, general self-efficacy and refocus on the plan, positive refocus, positive reappraisal, and putting in the perspective decrease while scores of acceptance, self-blame and catastrophizing increase. As the scores of psychological well-being increase self-esteem, general selfefficacy, refocus on the plan, positive refocus, positive reappraisal, and putting in the perspective scores increase in the same way; on the other hand, it shows that acceptance, self-blame, blaming others and catastrophizing scores decrease.

Table 3 shows the results that in line with the problem of the research the scores of self-esteem, general self-efficacy, hopelessness, self-blame, acceptance, rumination, positive refocus, refocus on the plan, positive reappraisal, putting it in perspective, blame destruction and blaming others together predicts psychological well-being or not. 
INVESTIGATION OF RELATIONSHIP BETWEEN PSYCHOLOGICAL WELL-BEING, SELF ESTEEM, PERCEIVED GENERAL SELF-EFFICACY, LEVEL OF HOPE AND COGNITIVE EMOTION REGULATION STRATEGIES

\begin{tabular}{llllll}
\hline \multicolumn{7}{c}{ Table 3: Stepwise Regression Analysis } \\
& Regarding the Prediction of Psychological Well-Being Scores & \\
\hline Variable & $\mathbf{B}$ & Std. Error & $\beta$ & $\mathbf{t}$ & $\mathbf{p}$ \\
\hline Constant & 143.629 & 11.620 & & 12.360 & .000 \\
\hline Self-Esteem & 1.863 & .232 & .366 & 8.040 & .000 \\
\hline Hopelessness & -7.877 & 1.450 & -.239 & -5.432 & .000 \\
\hline General Self-Efficacy & .831 & .189 & .170 & 4.384 & .000 \\
\hline Positive Reappraisal & 1.003 & .294 & .125 & 3.416 & .001 \\
\hline Acceptance & -.824 & .349 & -.083 & -2.358 & .019 \\
\hline Blaming Others & -.712 & .335 & -.073 & -2.125 & .034 \\
\hline $\mathrm{R}=0.745 \mathrm{R}^{2}=0.555 \mathrm{~F}_{(6-396)}=82.210 . \mathrm{p}=0.00$ & & & &
\end{tabular}

All variables were entered together in multiple linear regression analysis, and as seen in Table 3, self-esteem, hopelessness, general self-efficacy, positive reappraisal, acceptance, and blaming others show moderate and significant relationships with psychological wellbeing. Together, these variables explain about $56 \%$ of the total variance of psychological well-being $(R=0.745, R 2=0.555, p<01)$. According to the results of the regression analysis, the regression equation related to the prediction of the level of psychological well-being can be defined as psychological well-being $=143.629+1.863$, self-esteem -7.877 , hopelessness +0.831 , general self-efficacy +1.003 , positive reappraisal -0.824 , acceptance 0.712 , blaming others.

According to the standardized regression coefficients $(\beta)$ given in Table 3, the relative importance order of the predictive variables on psychological well-being; selfesteem, hopelessness, general self-efficacy, positive reappraisal, acceptance, and blaming others. When the t-test results related to the significance of the regression coefficients are examined, it can be stated that the variables in the equation are significant predictors. Self-blame, rumination, positive refocusing, refocus on the plan, putting in the perspective, and catastrophizing do not predict participants' psychological well-being. With this finding, it can be interpreted as a clue that participants' self-esteem, hopelessness, general self-efficacy, positive reappraisal, acceptance, and blaming others can be predictors about their level of psychological well-being.

\section{Discussion and Conclusion}

In this study, the relationship between individuals' psychological well-being levels and self-esteem, self-efficacy, hopelessness, cognitive emotion regulation strategies were examined. According to the results of the research, the correlations obtained showed that as the scores of hopelessness increased; psychological well-being, self-esteem, general self-efficacy, and adaptive cognitive emotion regulation scores decreased, on the other hand, as the scores of hopelessness increased, the scores of psychological well-being increased, self-esteem, general self-efficacy, and adaptive cognitive-emotional regulation strategy scores increased in the same way. $t$ is an expected result that psychological wellbeing, self-esteem, and self-efficacy scores will decrease with increasing hopelessness, which is defined as the individual's pessimism for the future (O'Connor, et al., 2000). 
INVESTIGATION OF RELATIONSHIP BETWEEN PSYCHOLOGICAL WELL-BEING, SELF ESTEEM, PERCEIVED GENERAL SELF-EFFICACY, LEVEL OF HOPE AND COGNITIVE EMOTION REGULATION STRATEGIES

Another finding obtained from correlations; psychological well-being, self-esteem, and general self-efficacy scores decrease, and hopelessness scores increase as scores of maladaptive cognitive emotion regulation strategies increase. In general, emotional responses facilitate the individual's functional adaptation to stressful or adverse conditions (Lasa-Aristu, et al., 2019). However, some people experience emotional difficulties that affect the functionality of this regulation mechanism (Werner \& Gross, 2010). Inadequate emotion regulation in response to stressful events can trigger pathological conditions (Compas et al., 2017; Denny, et al., 2009; Gross \& Thomson, 2007; Mennin, et al., 2007). Generally, maladaptive emotion regulation strategies have been associated with psychopathology in the literature.

According to the results of the research, self-esteem, general self-efficacy, hopelessness, adaptive, and maladaptive cognitive emotion regulation strategies predicted psychological well-being both individually and together as well. It was revealed that five variables explained $54.5 \%$ of the total variance of psychological wellbeing. Following the findings of our research, when the studies in the literature are examined, there are many types of research that self-esteem is a predictor of psychological well-being. Studies have found a significant relationship between selfesteem and psychological well-being (Dogan et al., 2013; Rosenberg et al., 1995; Xiang et al., 2019), and when self-esteem is high, psychological well-being is also found to be high (Kernis, 2003; Schilling, 2015). Another experimental study (Cheng \& Furnham, 2003; Chen et al., 2013; Disabato et al., 2016) confirmed that self-esteem is an important predictor of psychological well-being.

There are many studies in the literature on the relationship between emotion regulation strategies and subjective and psychological well-being (Gross \& John 2003; Haga, et al., 2009; Kuyumcu, 2013; McRae et al., 2012; Öztürk, 2019; Shiota, 2006; Uyar, 2019). Garnefski et al. (2001) defined 9 cognitive emotion regulation strategies. In this study, it was determined that out of 9 strategies mentioned, 8 strategies other than rumination had a low and moderate correlation with psychological well-being. These strategies were added to the regression analysis, and it was determined positive reappraisal, acceptance, and blaming others predicted psychological well-being. Positive reappraisal is a cognitive process involving an attempt to focus on the positive aspects of a negative event by reinterpreting the situation (Garnefski et al. 2001; Folkman \& Moskowitz, 2000). According to this finding, which is in line with the literature (Balzarotti, et al., 2016; Karademas, 2007; Öztürk, 2019; Shiota, 2006; Uyar, 2019), it can be said that individuals who use the positive reappraisal strategy have positive contributions to their psychological well-being. Also, in accordance with the literature (Anderson et al. 1994; Leary et al., 2007; Neff 2003; Nolen-Hoeksema 2000; Öztürk, 2019; Uyar, 2019), it was found that individuals who use the strategy of blaming others less, contribute positively to the psychological well-being. On the other hand, the acceptance strategy (Garnefski et al. 2001; Folkman \& Moskowitz, 2000) described in the literature as an "adaptive" strategy showed a negative correlation with the psychological well-being in this research. As a result of the regression analysis, it was found that it predicted 
INVESTIGATION OF RELATIONSHIP BETWEEN PSYCHOLOGICAL WELL-BEING, SELF ESTEEM, PERCEIVED GENERAL SELF-EFFICACY, LEVEL OF HOPE AND COGNITIVE EMOTION REGULATION STRATEGIES

psychological well-being negatively. Similar results were obtained in the Turkish sample, which especially looked at the relations with psychological well-being (Özen Rıza, 2016; Öztürk, 2019; Uyar, 2019).

General self-efficacy, another variable that predicts psychological well-being, is defined as a broad and stable sense of personal competence to deal effectively with various stressful situations (Aypay, 2010; Schwarzer \& Jerusalem, 1995). In the literature, Farsides and Woodfield (2003) and Duckworth et al. (2007) stated that self-efficacy is an important predictor of individual performance and motivation in different situations and environments. Moreover, it has been found that it is an important part of coping with the inevitable changes in life, and negative emotional experiences such as stress and anxiety can harm self-efficacy (Kelleher, 2016). Individuals with high self-efficacy have positive beliefs in their ability to cope with stressful situations and these beliefs have a significant relationship with positive emotional states such as psychological well-being, subjective well-being and life satisfaction (Freire et al., 2019; Priesac \& Alcock, 2015; Salvador \& Mayoral, 2011). Individuals with high self-efficacy prefer to do more challenging tasks and are more willing to solve problems (Graham, 2011). On the other hand, high selfefficacy increases resistance to depressive symptoms, anxiety, and helplessness. Bingöl et al. (2019) found that psychological resilience as a predictor of self-efficacy in their research. Tong and Shanggui (2004) also emphasized that general self-efficacy is also associated with mental and psychological well-being. Findings in the literature overlap with the findings of this study.

Another variable that predicts psychological well-being is the level of hopelessness. Snyder (2002) defined hope as a perceived capacity to derive paths on the way to desired goals. In general, it is defined as the perception of achieving the goals. Hopelessness is defined as a negative attitude towards the future and is associated with psychopathological conditions such as depression and schizophrenia (Beck et al., 1993; Lysaker et al., 2004). There are also research findings showing that hopelessness is also found at the clinical level in the general population (Haatainen et al., 2003). Hope is defined as a healing power, and hopeful people are found to be more resilient in adverse situations. Hope appears to have a protective function against adverse situations (Sar1 \& Tunç, 2016). In the research carried out in Turkey, in parallel with the findings of this research, there is evidence that hope is the predictor of life satisfaction, psychological resilience (Çelik, et al., 2017), self-efficacy (Kemer, 2006) and psychological well-being (Sarı \& Tunç, 2016).

According to the results of this study, psychological well-being is related to cognitive emotion regulation strategies, general self-efficacy perception, self-esteem and hopelessness, positive reappraisal, acceptance, and blaming others. Psychological wellbeing will increase as individuals use more positive reappraisal strategies against difficult life events, and as they use strategies to blame and accept others, general selfefficacy perceptions and self-esteem less and as hopelessness level decreases. According to this result, individual and group psychoeducational programs that support 
individuals' coping skills should be developed. Starting from primary school level efforts should be made to develop studies that will support each variable discussed in this study. It should be noted that this research has some limitations in addition to its remarkable findings. First of all, when considering the findings, it should be taken into consideration that a relational pattern is used in the research and random sampling is done. With the experimental or longitudinal studies, investigating the cause-effect relationship and the findings of the research can be examined more in-depth. Besides, another limitation of the research is that the research is carried out using scales based on self-assessment. Scales based on self-assessment carry the risk of reflecting the ideal or the favorable situation. Therefore, using other objective evaluation tools will make the research results more objective.

\section{About the Author}

Dr. O. Nejat Akfirat is a faculty member at Kocaeli University Faculty of Education, Department of Guidance \& Counselling. His fields of interest are psychosocial development, youth participation and gender. He completed his doctorate degree in the field of Educational Psychology at Ankara University, Faculty of Education in 2010.

\section{References}

Abela, J. R. Z. \& Seligman, M. E. P. (2000). The hopelessness theory of depression: A test of the diathesis-stress component in the inter-personal and achievement domains. Cognitive Therapy and Research, 24 (4), 361-378.

Abramson, L. Y., Alloy, L. B., \& Metalsky, G. I. (1989). Hopelessness depression-A theory-based subtype of depression. Psychological Review, 96(2), 358-372. https://doi.org/10.1037/0033-295x.96.2.358.

Akın, A. (2008). Psikolojik iyi olma ölçeğinin: geçerlik ve güvenirlik çalışması. Kuram ve Uygulamada Ĕ̆itim Bilimleri, 8(3), 721-750.

Akın, A. Demirci, İ., Yıldız, E., Gediksiz, E., \& Eroglu, N. (2012). The short form of the scales of psychological well-being (SPWB-42): The Validity and Reliability of the Turkish Version. Paper presented at the International Counseling and Education Conference, (ICEC 2012), May, 3-5, İstanbul.

Aldoa, A. \& Nolen-Hoeksama, S. (2010). Specifity of cognitive emotion regulation strategies: A transdiagnostic examination. Behavior Research and Therapy, 48, 974983.

Anderson, C. A., Miller, R. S., Riger, A. L., Dill, J. C., \& Sedikides, C. (1994). Behavioral and characterological styles as predictors of depression and loneliness: Review, refinement, and test. Journal of Personality and Social Psychology, 66, 549-558.

Andres, M. L., Richaud de Minzi, M. C., Castaneiras, C., Canet-Juric, L., \& RodriguezCarvajal, R. (2016). Neuroticism and depression in children: The role of cognitive emotion regulation strategies. The Journal of Genetic Psychology, 177(2), 55-71. 
INVESTIGATION OF RELATIONSHIP BETWEEN PSYCHOLOGICAL WELL-BEING, SELF ESTEEM, PERCEIVED GENERAL SELF-EFFICACY, LEVEL OF HOPE AND COGNITIVE EMOTION REGULATION STRATEGIES

Aslan, C. (2013). Özel eğitim okullarında çalışan öğretmenlerin umutsuzluk düzeylerinin belirlenmesi. International Journal of Social Science, 6 (7), 121-132.

Aypay, A. (2010). Genel öz yeterlik ölçeği'nin (GÖYÖ) Türkçe'ye uyarlama çalışması. İnönü Üniversitesi Ĕ̆itim Fakültesi Dergisi, 11 (2), 113-131.

Balzarotti, S., Biassoni, F. Villani, D., Prunas, A.,\& Velotti, P. (2016). Individual differences in cognitive emotion regulation: Implications for subjective and psychological well-being. Journal of Happiness Studies, 17(1), 125-143. DOI 10.1007/s10902-0149587-3

Bandura, A. (1977). Self-efficacy: toward a unifying theory of behavioral change. Psychological Review, 84 (2), 191-215.

Bandura, A. (1982). Self-efficacy mechanism in human agency. American Psychologist, 37 (2), 122-147.

Bandura, A. (1986). Social foundations of thought and action: A social cognitive theory. Englewood Cliffs, NJ: Prentice Hall.

Bandura, A. (1997). Self-efficacy: The exercise of control. New York: Freeman.

Beck, A. T., Steer, R. A., Beck, J. S., \& Newman, C. F. (1993). Hopelessness, depression, suicidal ideation, and clinical-diagnosis of depression. Suicide and Life-Threatening Behavior, 23(2), 139-145. https://doi.org/10.1111/j.1943-278X.1993.tb003 78.x.

Beck, A.T., Weissman, A., Lester, D., \& Trexler, L. (1974). The measurement of pessimism: The hopelessness scale. Journal of Consulting and Clinical Psychology, 42(6), 861-865.

Bingöl, T.Y., Vural Batık, M., Hoşoğlu, R., \& Fırıncı Kodaz, A. (2019) Psychological resilience and positivity as predictors of self-efficacy. Asian Journal of Education and Training, 5, (1), 63-69 10.20448/journal.522.2019.51.63.69

Button, E.J., Loan, P., Davies, J. \& Sonuga-Barke, E.J.S. (1997). Self-Esteem, eating problems, and psychological well-being in a cohort of schoolgirls aged 15-16: A questionnaire and interview study. International Journal of Eating Disorders, 21 (1)., 39-47

Büyüköztürk, Ş., Çokluk, Ö. \& Köklü, N. (2012). Sosyal bilimler için istatistik. Ankara, Pegem Akademi.

Chen, F. F., Jing, Y., Hayes, A., \& Lee, J. M. (2013) Two concept or two approaches? A bifactor analysis of psychological and subjective well-being. Journal of Happiness Studies, 14, 1033-1068. Doi:10.1007/s10902-012-9367-x

Cheng, H., \& Furnham, A. (2003). Attributional style and self-esteem as predictors of psychological well-being. Counselling Psychology Quarterly, 16(2), 121-130.

Cicchetti, D., Ackerman, B. P., \& Izard, C. E. (1995). Emotions and emotion regulation in developmental psychopathology. Development and Psychopathology, 7, 1-10.

Compas, B. E., Jaser, S. S., Bettis, A. H., Watson, K. H., Gruhn, M. A., Dunbar, J. P., Williams, E., \& Thigpen, J. C. (2017). Coping, emotion regulation, and psychopathology in childhood and adolescence: A meta-analysis and narrative review. Psychological Bulletin, 143(9), 939-991. https://doi.org/10.1037/bul0000110

Crocker, J. \& Park, L. E. (2004). The costly pursuit of self-esteem. Psychological Bulletin, $130,392-414$. 
INVESTIGATION OF RELATIONSHIP BETWEEN PSYCHOLOGICAL WELL-BEING, SELF ESTEEM, PERCEIVED GENERAL SELF-EFFICACY, LEVEL OF HOPE AND COGNITIVE EMOTION REGULATION STRATEGIES

Çelik, M., Sanberk, İ., \& Deveci, F. (2017). Öğretmen adaylarının yaşam doyumlarının yordayıcısı olarak psikolojik dayanıklılık ve umutsuzluk. İlköğretim Online, 16 (2), 654-662,

Çuhadaroğlu, F. (1986). Ergenlerde benlik saygısı. Yayınlanmamış uzmanlık tezi, Ankara: Hacettepe Üniversitesi.

Denny, B., Silvers, J., \& Ochsner, K. N. (2009). How we heal what we don't want to feel: The functional neural architecture of emotion regulation. In A. M. Kring \& D. M. Sloan (Eds.), Emotion regulation and psychopathology: A transdiagnostic approach to etiology and treatment (pp. 59-87). New York, NY: Guilford Press

Disabato, D. J., Goodman, F. R., Kashdan, T. B., Short, J. L., \& Jarden, A. (2016). Different types of well-being? A cross-cultural examination of hedonic and eudaimonic well-being. Psychological Assessment, 28, 471-482. doi: 10.1037/pas0000209

Dogan, T., Totan, T., \& Sapmaz, F. (2013). The role of self-esteem, psychological wellbeing, emotional self-efficacy, and affect balance on happiness: A path model. European Scientific Journal, 9(20), 31-42.

Dubois, D. L. \& Flay, B. R. (2004). The healthy pursuit of self-esteem: Comment on and alternative to the Crocker and Park (2004) formulation. Psychological Bulletin, 130, 415-420.

Duckworth, A.L., Peterson, C., Matthews, M.D. \& Kelly, D.R. (2007). Grit: Perseverance and passion for long-term goals. Journal of Personality and Social Psychology, 92(6): 1087-1101. Available at: https://doi.org/10.1037/0022-3514.92.6.1087.

Durak, A. \& Palabıyık R. (1994). Beck umutsuzluk ölçeği geçerlik çalışması. Kriz Dergisi 2(2), 311-319.

Farsides, T. \& Woodfield, R. (2003). Individual differences and undergraduate academic success: The roles of personality, intelligence, and application. Personality and Individual Differences, 34(7): 1225-1243. https://doi.org/10.1016/s01918869(02)00111-3.

Fergusson, D. M. \& Lynskey, M. T. (1996). Adolescent resiliency to family adversity. Journal of Child Psychology and Psychiatry and Allied Disciplines, 37, 281-292.

Folkman, S., \& Moskowitz, J. T. (2000). Stress, positive emotion, and coping. Current Directions in Psychological Science, 9, 115-118.

Franklin, J. C., Ribeiro, J. D., Fox, K. R., Bentley, K. H., Kleiman, E. M., Huang, X. Y. N., et al. (2017). Risk factors for suicidal thoughts and behaviors: A meta-analysis of 50 years of research. Psychological Bulletin, 143(2), 187-232. https://doi.org/10.1037/bul0000084.

Freire, C., Mar Ferradás, M., Núñez, J.C., Valle, A., \& Vallejo, G. (2019). Eudaimonic wellbeing and coping with stress in university students: The mediating/moderating role of self-efficacy. International Journal of Environmental Research and Public Health, 16 (1),48, 1-15. doi:10.3390/ijerph16010048

Garnefski, N., \& Kraaij, V. (2006). Relationships between cognitive emotion regulation strategies and depressive symptoms: A comparative study of five specific samples. Personality and Individual differences, 40(8), 1659-1669. 
Garnefski, N., \& Kraaij, V. (2007). The cognitive emotion regulation questionnaire psychometric features and prospective relationships with depression and anxiety in adults. European Journal of Psychological Assessment, 23(3), 141-149.

Garnefski, N., \& Kraaij, V. (2016). Specificity of relations between adolescents' cognitive emotion regulation strategies and symptoms of depression and anxiety. Cognition and Emotion, 1-8. https://doi.org/10.1080/02699931.2016.1232698

Garnefski, N., Kommer, T. V. D., Kraaij, V., Teerds, J., Legers-tee, J., \& Onstein, E. (2002). The relationship between cognitive emotion regulation strategies and emotional problems: comparison between a clinical and a non-clinical sample. European Journal of Personality, 16, 403-420.

Garnefski, N., Kraaij, V. \& Spinhoven, P. (2001). Negative life events, cognitive emotion regulation and emotional problems. Personality and Individual Differences, 30, (1311-1327).

Graham, S. (2011). Self-efficacy and academic listening. Journal of English for Academic Purposes, 10(2): 113-117. https://doi.org/10.1016/j.jeap.2011.04.001.

Gross, J. J. (2001). Emotion regulation in adulthood: Timing is everything. Current Directions in Psychological Science, 10, 214-219.

Gross, J. J., \& John, O. P. (2003). Individual differences in two emotion regulation processes: Implications for affect, relationships, and well-being. Journal of Personality and Social Psychology, 85, 348-362.

Gross, J. J., \& Thompson, R. A. (2007). Emotion regulation: Conceptual foundations. In J. J. Gross (Ed.), Handbook of emotion regulation (pp. 3-24). New York, NY: Guilford Press.

Haatainen, K. M., Tanskanen, A., Kylma, J., Honkalampi, K., Koivumaa-Honkanen, H., Hintikka, J., et al. (2003). Stable hopelessness and its predictors in a general population: A 2-year follow-up study. Suicide and Life-Threatening Behavior, 33(4), 373-380. http://doi.org/10.1521/suli.33.4.373.25237.

Haga, S. M., Kraft, P., \& Corby, E. (2009). Emotion regulation: Antecedents and wellbeing outcomes of cognitive reappraisal and expressive suppression in crosscultural samples. Journal of Happiness Studies, 10, 271-291.

Hobfoll, S. E. (1989). Conservation of resource: A new attempt at conceptualizing tress. American Psychologist,44(3), 513-524.

Holdcraft, C. \& Williamson, C. (1991). Assessment of hope in psychiatric and chemically dependent patients. Applied Nursing Research, 4(3), 129-134.

Huppert, F. A. (2009). Psychological well-being: Evidence regarding its causes and consequences. Applied Psychology: Health and Well-being, 1, 137-164.

Kalaycı, Ş. (Ed.) (2009). SPSS uygulamalı çok değişkenli istatistik teknikleri (4.bask1). Ankara: Asil Yayıncilık.

Karademas, E. C. (2007). Positive and negative aspects of well-being: Common and specific predictors. Personality and Individual Differences, 43, 277-287. 
Karaırmak, Ö., \& Siviş-Çetinkaya, R. S. (2011). Benlik saygısının ve denetim odağının psikolojik sağlamlık üzerine etkisi: Duyguların aracı rolü. Türk Psikolojik Danışma ve Rehberlik Dergisi, 4(35), 30-41.

Karasar, N. (2012). Bilimsel araştırma yöntemleri. Ankara: Nobel Yayın Dağıtım.

Kelleher, J. (2016). You're ok, i'm ok. Delta Kappan, 97(8): 70-73.

Kemer, G. (2006). The role of self-efficacy, hope, and anxiety in predicting university entrance examination scores of eleventh grade students. Yayımlanmamış Yüksek Lisans Tezi, Ortadoğu Teknik Üniversitesi, Ankara.

Kernis, M. H. (2003). Toward a conceptualization of optimal self-esteem. Psychological Inquiry, 14, 1-26.

Keyes, C. L. M., Shmotkin, D. \& Ryff, C. D. (2002). Optimizing Well-Being: The empirical encounter of two traditions. Journal of Personality \& Social Psychology, 82, 6, 10071023.

Kraaij, V., Arensman, E., Garnefski, N., \& Kremers, I. (2007). The role of cognitive coping. Journal of Interpersonal Violence, 22(12), 1603-1612.

Kraaij, V., Garnefski N., \& Vlietstra A. (2008). Cognitive coping and depressive symptoms in definitive infertility: a prospective study. Journal of Psychosomatic Obstetrics $\mathcal{E}$ Gynecology, 29(1), 9-16.

Kuyumcu, B. (2013). The predictive power of university students' positive-negative moods in their psychological well-being. Journal of Theoretical Educational Science, $6(1), 62-76$.

Kylma, J. (2005). Dynamics of hope in adults living with HIV/AIDS: a substantive theory. Journal of Advanced Nursing, 52, 620-630.

Lasa-Aristu, A., Delgado-Egido, B., Holgado-Tello, F.P., Amor, P.J., \& Domínguez Sánchez, F. (2019). Profiles of cognitive emotion regulation and their association with emotional traits. Clínica y Salud 30(1) 33-39. http://dx.doi.org/10.5093/clysa2019a6.

Leary, M. R., Tate, E. B., Adams, C. E., Allen, A. B., \& Hancock, J. (2007). Self-compassion and reactions to unpleasant self-relevant events: The implications of treating oneself kindly. Journal of Personality and Social Psychology, 92, 887-904.

Liu, Q., Shono, M, .\& Kitamura T. (2009). Psychological well-being, depression, and anxiety in Japanese university students. Depression and Anxiety, (26), 99-105.

Lopez, S. J., \& Snyder, C. R. (Eds.). (2004). Positive psychological assessment: A handbook of models and measures. Washington, DC: American Psychological Association.

Lysaker, P. H., Davis, L. W., \& Hunter, N. L. (2004). Neurocognitive, social and clinical correlates of two domains of hopelessness in schizophrenia. Schizophrenia Research, 70(2-3), 277-285. doi.org/10.1016/j.schre s.2004.01.007.

Mac Giollabhui, N., Hamilton, J. L., Nielsen, J., Connolly, S. L., Stange, J. P., Varga, S., et al. (2018). Negative cognitive style interacts with negative life events to predict first onset of a major depressive episode in adolescence via hopelessness. Journal of Abnormal Psychology, 127(1), 1-11. https://doi.org/10.1037/abn0000301. 
INVESTIGATION OF RELATIONSHIP BETWEEN PSYCHOLOGICAL WELL-BEING, SELF ESTEEM, PERCEIVED GENERAL SELF-EFFICACY, LEVEL OF HOPE AND COGNITIVE EMOTION REGULATION STRATEGIES

Marchetti, I., Koster, E. H. W., Klinger, E., \& Alloy, L. B. (2016). Spontaneous thought and vulnerability to mood disorders. Clinical Psychological Science, 4, 835- 857. https://doi.org/10.1177/2167702615622383.

McGee, R., Wolfe, D., \& Olson, J. (2001). Multiple maltreatment, attribution of blame, and adjustment among adolescents. Development and Psychopathology, 13, 827-846.

McRae, K., Jacobs, S. E., Ray, R. D., John, O. P., \& Gross, J. J. (2012). Individual differences in reappraisal ability: Links to reappraisal frequency, well-being, and cognitive control. Journal of Research in Personality, 7, 253-262.

Mennin, D. S., Holoway, R. M., Fresco, D. M., Moore, M. T., \& Heimberg, R. G. (2007). Delineating components of emotion and its dysregulation in anxiety and mood $\begin{array}{llll}\text { psychopathology. Behavior 284-302. } & \text { 38, }\end{array}$ https://doi.org/10.1016/j.beth.2006.09

Morsünbül, Ü. (2011). Ergenlikte özerkliğin ve kimlik biçimlenmesinin öznel iyi oluş üzerindeki etkisi. Yayımlanmamış Doktora Tezi, Ankara Üniversitesi Eğitim Bilimleri Enstitüsü, Ankara.

Neff, K. D. (2003). The development and validation of a scale to measure self-compassion. Self and Identity, 2, 223-250.

Nolen-Hoeksema, S. (2001). Gender differences in depression. Current Directions in Psychological Science, 10, 173-176.

O'Connor, R. C., Connery, H., \& Cheyne, W. M. (2000). Hopelessness: The role of depression, future directed thinking and cognitive vulnerability. Psychology, Health $\mathcal{E}$ Medicine, 5(2), 155-161.

Onat, O \& Otrar, M. (2010). Bilişsel duygu düzenleme ölçeğinin Türkçeye uyarlanması: Geçerlik ve güvenirlik çalışmaları. Marmara Üniversitesi Ĕ̆̈itim Bilimleri Dergisi, 31, 123-143.

Özen Rıza, S. (2016). Evli bireylerin bilişsel duygu düzenleme stratejilerinin psikolojik iyi oluşlarn ve evlilik doyumlarn ile ilişkisinin incelenmesi. Yayımlanmamış Yüksek Lisans Tezi. Işık Üniversitesi Sosyal Bilimler Enstitüsü, İstanbul.

Öztürk, H. (2019). Üniversite öğrencilerinde duygu düzenleme stratejileri ile psikolojik sağlamlık arasındaki ilişkinin incelenmesi. Yayımlanmamış Yüksek Lisans Tezi. Hasan Kalyoncu Üniversitesi Sosyal Bilimler Enstitüsü, Gaziantep.

Peterson, C., Ruch, W., Beermann, U., Park, N., \& Seligman, M. E. (2007). Strengths of character, orientations to happiness, and life satisfaction. The Journal of Positive Psychology, 2(3), 149-156.

Priesack, A., \& Alcock, J. (2015). Well-Being and self-efficacy in a sample of undergraduate nurse students: A small survey study. Nurse Education Today, 35, e16-e20. https://doi.org/10.1016/j.nedt.2015.01.022

Rosenberg, M. (1965). Society and the adolescent: Self-image. Princeton: Princeton University Press.

Rosenberg, M., Schooler, C., Schoenbach, C., \& Rosenberg, F. (1995). Global self-esteem and specific self-esteem: Different concepts, different outcomes. American Sociological Review, 60(1), 141-156. 
Ryan, R. M. \& Deci, E. L. (2001). On happiness and human potentials: A review of research on hedonic and eudemonic well-being. Annual review of psychology, 52(1), 141-166.

Ryff, C. D. (1989). Happiness is everything, or is it? Explorations on the meaning of psychological well-being. Journal of Personality and Social Psychology, 57(6) 10691081.

Ryff, C. D. (1995). Psychological well-being in adult life. Current Directions in Psychological Science, 4(4), 99-104.

Ryff, C. D. \& Keyes, C.L.M. (1995). The structure of psychological well-being revisited. Journal of Personality and Social Psychology, 69, 4, 719- 727

Ryff, C. D., \& Singer, B. H. (2006). Know thyself and become what you are: A eudaimonic approach to psychological well-being. Journal of Happiness Studies, 9(1), 13-39.

Salvador, C. \&. Mayoral, L. (2011). Entrepreneurial self-efficacy and life satisfaction in the ICT sector: A study of gender differences in Argentina. Journal of Basic and Applied Scientific Research, 1(3): 242-251.

Sarı, T. \& Tunç, E. (2016). Examining the predictors of subjective and psychological wellbeing of university students. International Journal of Social Science, 45, 291-302.

Scherbaum, C.A., Cohen-Charash, Y. \& Kern, M.J. (2006). Measuring general self-efficacy: A comparison of three measures using item response theory. Educational and Psychological Measurement, 66(6), 1047-1063.

Schilling, K. (2015). Examining the role of self-esteem in the association between emotional vulnerability and psychological well-being. Master's thesis. University of Dayton: Ohio.

Scholz, U., \& Schwarzer, R. (2005). The general self-efficacy scale: Multicultural validation studies. The Journal of Psychology, 139, (5), 439-457.

Schroevers, M., Kraaij, V., \& Garnefski, N. (2007). Goal disturbance, cognitive coping strategies, and psychological adjustment to different types of stressful life event. Personality and Individual Differences, 43(2), 413-423.

Schwarzer, R. \& Jerusalem, M. (1995). Generalized self-efficacy scale in J. Weiman, S. Wright, \& M. Johnston (Ed). Measures in health psychology: A users' portfolio, causal and control beliefs. pp. 35-37, Winderser, UKNFER-NELSON.

Seber, G. (1991). Beck Umutsuzluk Ölçeğinin geçerliği ve güvenirliği üzerine bir çalışma. Doçentlik Tezi, Anadolu Üniversitesi, Eskişehir.

Shiota, M. (2006). Silver linings and candles in the dark: Differences among positive coping strategies in predicting subjective well-being. Emotion, 6, 335-339.

Snyder, C. R. (2002). Hope theory: Rainbows in the mind. Psychological Inquiry, 13(4), 249275. http://doi.org/10.1207/S1532 7965P LI130 401.

Tabachnick, B. G. \& Fidell L. S. (2007). Using multivariate statistics. USA, Pearson Education.

Taylor, S. E., \& Stanton, A. L. (2007). Coping resources, coping processes, and mental health. Annual Review of Clinical Psychology,3,377-401. 
Thompson, R. A. (1991). Emotional regulation and emotional development. Educational Psychology Review, 3, 269-307.

Tong, Y. \& Shanggui, S. (2004). A Study on general self-efficacy and subjective well-being of low ses college students in a Chinese university. College Students Journal, 38 (4), 637-642.

Uyar, M. (2019). Beliren yetişkinlik dönemindeki bireylerin psikolojik iyi oluş düzeylerini yordamada bağlanma tarzları ve bilişsel duygu düzenlemenin rolünün incelenmesi. Yayımlanmamış Yüksek Lisans Tezi. Maltepe Üniversitesi Sosyal Bilimler Enstitüsü, İstanbul.

Wang, C., \& Castañeda-Sound, C. (2008).The role of generational status, self-esteem, academic self-efficacy, and perceived social support in college students' psychological well-being. Journal of College Counseling, 11(2), 01-118.

Weishaar, M. E., \& Beck, A. T. (1992). Hopelessness and suicide. International Review of Psychiatry, 4, 177-184.

Werner, K., \& Gross, J. J. (2010). Emotion regulation and psychopathology: A conceptual framework. In A. Kring \& D. Sloan (Eds.), Emotion regulation and psychopathology: A transdiagnostic approach to etiology and treatment (pp. 1337). New York, NY: Guilford Press.

Xiang, Z., Tan, S., Kang, Q. et al. (2019). Longitudinal effects of examination stress on psychological well-being and a possible mediating role of self-esteem in chinese high school students. Journal of Happiness Studies, 20(1), 283-305. https://doi.org/10.1007/s10902-017-9948-9. 
Author(s) will retain the copyright of their published articles agreeing that a Creative Commons Attribution 4.0 International License (CC BY 4.0) terms will be applied to their work. Under the terms of this license, no permission is required from the author(s) or publisher for members of the community to copy, distribute, transmit or adapt the article content, providing a proper, prominent and unambiguous attribution to the authors in a manner that makes clear that the materials are being reused under permission of a Creative Commons License. Views, opinions and conclusions expressed in this research article are views, opinions and conclusions of the author(s). Open Access Publishing Group and European Journal of Education Studies shall not be responsible or answerable for any loss, damage or liability caused in relation to/arising out of conflicts of interest, copyright violations and inappropriate or inaccurate use of any kind content related or integrated into the research work. All the published works are meeting the Open Access Publishing requirements and can be freely accessed, shared, modified, distributed and used in educational, commercial and non-commercial purposes under a Creative Commons Attribution 4.0 International License (CC BY 4.0). 